\title{
ISSUES RELATED TO DEFINITION OF AN APPROPRIATE DEPRECIATION METHOD FOR THE PURPOSES OF CALCULATION IN A METALLURGICAL COMPANY
}

\author{
Andrea SUŠKOVÁ, Jana BUCHTOVÁ \\ VSB - Technical University of Ostrava, Ostrava, Czech Republic, EU, suskova@vsb.cz, buchtova@vsb.cz
}

https://doi.org/10.37904/metal.2021.4275

\begin{abstract}
This paper defines the individual types of depreciation and the methods for depreciation of tangible fixed assets in a metallurgical company. It analyses the potential impact on the economic results and evaluates how the depreciation methods were applied. The paper intends to propose the optimal depreciation method for the purposes of calculation in the company and quantify the impact of such method on its budgets and standards.
\end{abstract}

Keywords: Metallurgical company, calculation, depreciation method, tangible fixed assets

\section{INTRODUCTION}

The simplest definition of depreciation of tangible fixed assets stipulates that it is a financially expressed value of wear and tear of assets for the specified period. It is an indicator of gradual decrease in value of assets. However, depreciation has more functions. In accounting, the absolute majority of authors tends to the view that depreciation of tangible fixed assets represents the transfer of the original price of assets in operational costs, and that depreciation is not a source of funding of the business needs [1]. In contrast to the above, the practice of financial management comprehends the depreciation also as an internal source of funding, since, in the long term, a well-functioning company must return such depreciation in replacement of fixed assets. Based on the above, we can thus certainly define three fundamental functions of depreciation [2]:

- Depreciation expresses wear and tear of fixed assets and decreases their value in the balance sheet;

- Depreciation allows a gradual transfer of the value of depreciated assets in costs;

- Depreciation is an internal source of funding.

In the accounting in the Czech Republic, we encounter tax and accounting depreciations; in the business practice, management or cost depreciation is also often applied. In the following part of the paper, the principles of the above types of depreciation will be briefly presented.

\section{DEFINITIONS OF THE INDIVIDUAL TYPES OF DEPRECIATION}

In the Czech Republic, depreciation of assets is defined by Act No. 563/1991 Coll., Accounting Act, Act No. 586/1992 Coll., Income Taxes Act, Act No. 151/1997 Coll., Property Valuation Act, and also by Czech Accounting Standard No. 013. The above legislative requirements stipulate the conditions for accounting and tax depreciations. Where the term "assets" is further mentioned in the text, it is understood as both tangible and intangible assets. The first definition is related to the accounting depreciation.

\subsection{Accounting Depreciation}

The accounting depreciation is legislatively stipulated by Act No. 563/1991 Coll., Accounting Act, implementing decrees, including, without limitation, Decree No. 500/2002 Coll. and the Czech Accounting Standards. Especially Section 56 of Decree No. 500/2002 Coll. defines the depreciation of assets and its methods as 
follows: "Depreciated intangible and tangible assets, or any of their parts, are depreciated on the valuation, as specified in Sections 47, 61, 61a and in Articles 25 and 27 of the Act, gradually in the course of their use. The course of use can be expressed in a different manner than in relation to time, for example, to revenues from production" [3]. The above specified legal regulations related to the accounting depreciation provide general guidance; nevertheless, for this type of depreciation, they place emphasis on application of the accrual principle based on substantive context. The accounting entity defines such depreciation itself, mostly on the basis of the actual period of use of fixed assets. The right accounting depreciation must represent a true and fair view of the state of accounts and the financial position of the accounting entity.

\subsection{Tax Depreciation}

From the tax point of view, Section 26 (5) of Act No. 586/1992 Coll., on income taxes, defines depreciation of fixed assets as follows: "For the purposes of this Act, depreciation means comprising of depreciation on tangible assets registered with the taxpayer, and related to provision of taxable income, in the expense (costs) for provision of that income [4]. The above thus emphasizes mainly the cost function of depreciation. The characteristics of tax depreciation is that the fiscal policy of the state plays a non-negligible role in determination of its amount and definition of the period for which the assets are depreciated. It is a certain form of consensus between the possibilities of the state and the business requirement [5]. However, the Income Taxes Act also defines, amongst other things, the terms related to depreciation of assets, such as the acquisition price of assets, the balance price of assets, the depreciation categories and the entry price of assets. The tax depreciation is strictly governed by the provisions of the above Act, primarily in determination of the depreciation category which defines the statutory period of depreciation, as well as the maximum amount of depreciation recognised as tax-deductible costs. As follows from the above specified definitions of accounting and tax depreciations and their different functions, there is, or there must be, a difference in their amounts. Unless there are any compelling reasons for that, the same values in accounting and tax depreciations indicate a wrongly defined depreciation policy of the accounting entity. In fact, the differences arise not only due to different depreciation methods, but also due to a different determination of depreciation period, and mainly due to a different definition of depreciation base. The last-mentioned point of view is primarily related to another type of depreciation of assets - cost depreciation. This dual concept is applied both for depreciation and for some of the asset valuation principles, where it aims to reflect wear and tear of assets in a "fairer" manner in comparison to financial accounting; therefore, it is common to calculate it rather in relation to revenues from production than in relation to time; moreover, it is calculated from fair values, not from the historical cost [7].

\subsection{Cost (Management) Depreciation}

Management accounting is often linked to controlling, where relevant, and thus the cost depreciation can sometimes be referred to as controlling. The cost depreciation follows from the principles of management accounting, where the connection between costs and revenues from production is fundamental. Depreciations may differ not only in their amount, but also, for example, due to the fact that some controlling depreciation may not even appear in financial accounting [6]. This can be caused by the original investments low in price, not corresponding to the current higher acquisition value of a given asset or to the value of assets reduced by their subsidies in the accounts, which significantly affects the fair depreciation base of the assets. The use of controlling depreciation is also justified in cases where the assets have already been subject to accounting and tax depreciation; however, such assets are still used by the company and play a role in generating its revenues. In practice, such use appears in particular in cost and price calculations where, using its revenues, the company seeks to have a sufficient financial envelope for re-acquisition of worn-down assets. Due to its fixed character, the value of depreciation is also reflected in the company's indicators. The realistic representation of depreciation may significantly affect the company's information and, subsequently, further 
management decisions, such as the definition of the company's break-even point or the decision on existing capacities.

If the company uses complex technologies, as it is the case of metallurgical companies, the values of defined depreciation are represented by amounts which significantly affect not only the tax base at the end of each accounting and fiscal year, but also the standards and calculations in the company. In the following case study, we will provide a comparison of the values of depreciation in financial accounting and controlling and quantify their impact on the calculations in the company.

\section{CASE STUDY}

For the purposes of this paper, we chose the Cleaning and Machining Shop Centre, which forms part of an unnamed metallurgical company in the Czech Republic. Knock-out of castings from the moulds is followed by a cycle of finishing operations according to the customers' requirements. Scorched sand and cores are removed from the castings using the shot blasting and knock-out machines. Furthermore, modifications are made by means of grinding, machining, welding and other operations, if needed. All the above works are ensured by the machinery which is part of the equipment of the metallurgical centre. This includes especially shot blasting machines, grinding machines, milling machines, lathes, drills, etc. Over the years, the Cleaning and Machining Shop Centre, included in this paper, acquired the above technologies in order to ensure a longlasting quality of final products manufactured by the company. For the purposes of modelling of impact of depreciation on the calculations in the company, the time aspect of acquisition of the above technologies will not be considered, only the manner of acquisition and quantification of depreciation will be taken into account. The company's accounting records showed that some of the technologies with a higher acquisition price, mostly over CZK 1 million, were included in the company's subsidy programmes. As a result, the subsidy on the above production technologies covered less than $50 \%$ of the entry price of the machinery. Everything was properly registered and recognised in accordance with the legislative requirements. Under Section 29 (1) of Act No. 586/1992 Coll., on income taxes, the entry (acquisition) price of assets was decreased by the subsidies received, since the company did not recognise those funds in profit or loss. The above accounting transaction was executed for 9 technologies of the Cleaning and Machining Shop Centre, where the entry price of such machinery was thus reduced by CZK 23.3 million. Table 1 provides an overview of all production technologies of the Cleaning and Machining Shop Centre. It is clear which technologies were acquired through subsidies and which not.

Table 1 Overview of Technologies of the Cleaning and Machining Shop Centre, Entry Prices and Depreciation (in whole CZK)

\begin{tabular}{|c|c|c|c|c|c|c|c|c|}
\hline \multirow[b]{2}{*}{ Article name } & \multirow[b]{2}{*}{ Grant } & \multirow{2}{*}{$\begin{array}{c}\text { Depreciation } \\
\text { category }\end{array}$} & \multicolumn{2}{|c|}{\begin{tabular}{|l|} 
Number of deprec. (in month) \\
\end{tabular}} & \multicolumn{2}{|c|}{ Monthly depreciation } & \multicolumn{2}{|c|}{ Acquisition price } \\
\hline & & & \begin{tabular}{|c|}
$\begin{array}{c}\text { Based on } \\
\text { depr.category }\end{array}$ \\
\end{tabular} & $\begin{array}{c}\text { Based on } \\
\text { oper.lifetime }\end{array}$ & Cost & Accounting & Nominal & Accounting \\
\hline Vrtačka strojni s autoposunem & NO & 2 & 60 & 96 & 842.18 & $1,347.48$ & $80,848.80$ & $80,848.80$ \\
\hline Vrtačka řadová VR42B-CE2 & $\mathrm{NO}$ & 2 & 60 & 96 & $6,576.86$ & $10,522.97$ & $631,378.34$ & $631,378.34$ \\
\hline UNIVERSÁLNÍ HROTOVÝ SOUSTRUH SV 18 RD/1250 & NO & 2 & 60 & 96 & $4,781.25$ & $7,650.00$ & $459,000.00$ & $459,000.00$ \\
\hline Trens SOUSTRUH CNC 1500 SE520 & NO & 2 & 60 & 180 & $5,817.20$ & $17,451.61$ & $1,047,096.50$ & $1,047,096.50$ \\
\hline Trens VERTIKÁLNÍ OBRÁBĚCI CENTRUM MC100VA & $\mathrm{NO}$ & 2 & 60 & 180 & $11,876.11$ & $35,628.32$ & $2,137,699.00$ & $2,137,699.00$ \\
\hline Tryskaci zařizeni AGTOS & YES & 2 & 60 & 216 & $42,852.09$ & $80,441.93$ & $9,256,052.00$ & $4,826,516.00$ \\
\hline KOVOSVIT MAS HORIZONTKA MCV 1012 & YES & 2 & 60 & 120 & $13,930.73$ & $11,144.58$ & $1,671,687.00$ & $668,674.80$ \\
\hline RETOS - VYVRTÁVAČKA STOLOVÁ W100A & YES & 2 & 60 & 120 & $17,328.34$ & $13,862.67$ & $2,079,400.80$ & $831,760.32$ \\
\hline NEWTECH Soustruh MS-NL1500SMC/500 & YES & 2 & 60 & 180 & $22,500.00$ & $27,000.00$ & $4,050,000.00$ & $1,620,000.00$ \\
\hline NEWTECH Soustruh MORI SEIKI NL2000 SMC & YES & 2 & 60 & 180 & $23,333.33$ & $28,000.00$ & $4,200,000.00$ & $1,680,000.00$ \\
\hline TOS Olomouc FRÉZKA FGU32 & NO & 2 & 60 & 96 & $5,650.61$ & $9,040.98$ & $542,458.66$ & $542,458.66$ \\
\hline DMG MORI SEIKI - CNC NT 4250DCG/1500SZ & YES & 2 & 60 & 216 & $39,451.81$ & $56,810.61$ & $8,521,592.00$ & $3,408,636.80$ \\
\hline TAJMAC ZPS Obráběci centrum MCFV1680 Standard & YES & 2 & 60 & 180 & $15,550.90$ & $46,652.70$ & $2,799,162.00$ & $2,799,162.000$ \\
\hline Tryskaci zařizeni AGTOS - komorové, typ HT-13.21 & YES & 2 & 60 & 216 & $50,868.10$ & $73,250.06$ & $10,987,509.50$ & $4,395,003.80$ \\
\hline KOVOSVIT - Frézovaci a vrtaci centrum & YES & 2 & 60 & 120 & $11,657.33$ & $23,314.67$ & $1,398,880.00$ & $1,398,880.00$ \\
\hline TOS VARN. - RENISHAW RMP 60 měřici sonda & NO & 2 & 60 & 60 & $1,047.33$ & $1,047.33$ & $62,840.00$ & $62,840.00$ \\
\hline Soustruh SU 63A/1500 vč.lic.desky & $\mathrm{NO}$ & minor assets & 24 & 60 & 583.33 & $1,458.33$ & $35,000.00$ & $35,000.00$ \\
\hline TOTAL & & & $\mathbf{x}$ & $\mathbf{x}$ & $274,647.51$ & $444,624.25$ & $49,960,604.60$ & $26,624,955.02$ \\
\hline
\end{tabular}


The adjustment of the entry price in the accounting value of assets is the only statutory adjustment made due to the subsidy, provided for acquisition of assets. Table 1 clearly shows that thanks to the subsidy, for example, the depreciation category or the number of planned depreciations were not subject to any adjustment. The planned values of depreciations only changed with the reduction of the entry price of assets resulting from the subsidy provided. Figure 1 shows the adjustment of entry prices resulting from the recognition of the subsidy.

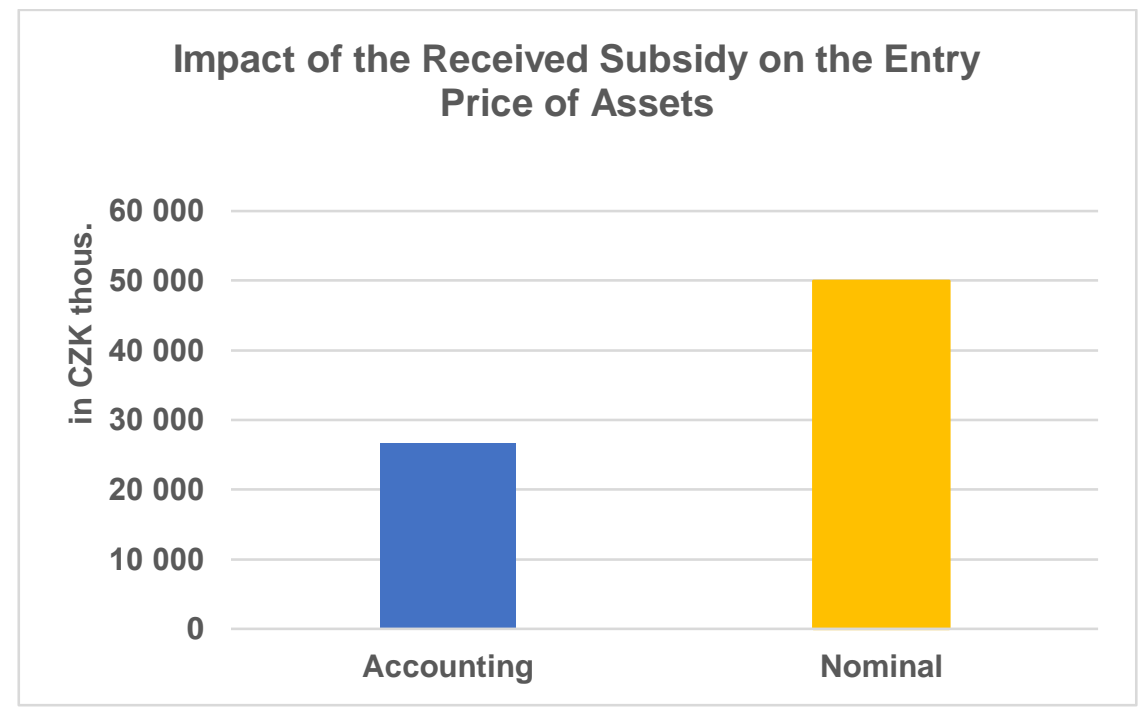

Figure 1 Impact of the Received Subsidy on the Entry Price of Assets (in CZK thous.)

However, significant adjustments were made after obtaining relevant data, which will be used for further management decision-making tasks. Mainly for the purposes of calculations, it is necessary to maintain the actual acquisition prices of assets, at least for newly acquired assets, or to determine replacement prices for the assets acquired as used. The aim is to reflect a proportional part of the value of assets in the calculation, where such part the most quantifies the actual cost consumed in manufacture or processing of the product in question. This adjustment is already apparent in Table 1, in the column "Monthly depreciation - Cost" which is based on the nominal acquisition price, thus without an adjustment due to the subsidy, and on the number of months of depreciation determined on the basis of an operating lifetime of the production technology. The operating lifetime of the production technology was defined by the Economic Department in cooperation with the Technology Department, which has the technical documents for the specified technological equipment and also the data on the use of the above capacities in the company's manufacture programme. On the basis of this qualified estimate, the number of months of depreciation related to the individual machines was adjusted thanks to their so-called operating lifetime. The significant difference in the value of monthly accounting and cost depreciations for production technologies of the Cleaning and Machining Shop Centre is appropriately documented in Figure 2. Although the depreciation base was the entry price without adjustment due to the subsidy, the value of the cost depreciation in comparison to the accounting depreciation is lower by CZK 169977 . The value of the monthly depreciation is reduced by $38 \%$. The reduction was the result of a change in the period of depreciation given by the number of months, where, for example, the operating lifetime of the most expensive technologies was set as twice the maximum value for the tax depreciation. The period of depreciation of assets set in this manner, and the depreciation subsequently defined in management accounting and business plans, perform their function of an internal source of funding. Since if we take into consideration the long physical lifetime of the assets, the funds acquired through depreciation can cover not only the future value of replacement of an impaired source, but also major events, such as planned maintenance actions and general overhauls, should the original value of assets be adjusted by such costs [8]. 


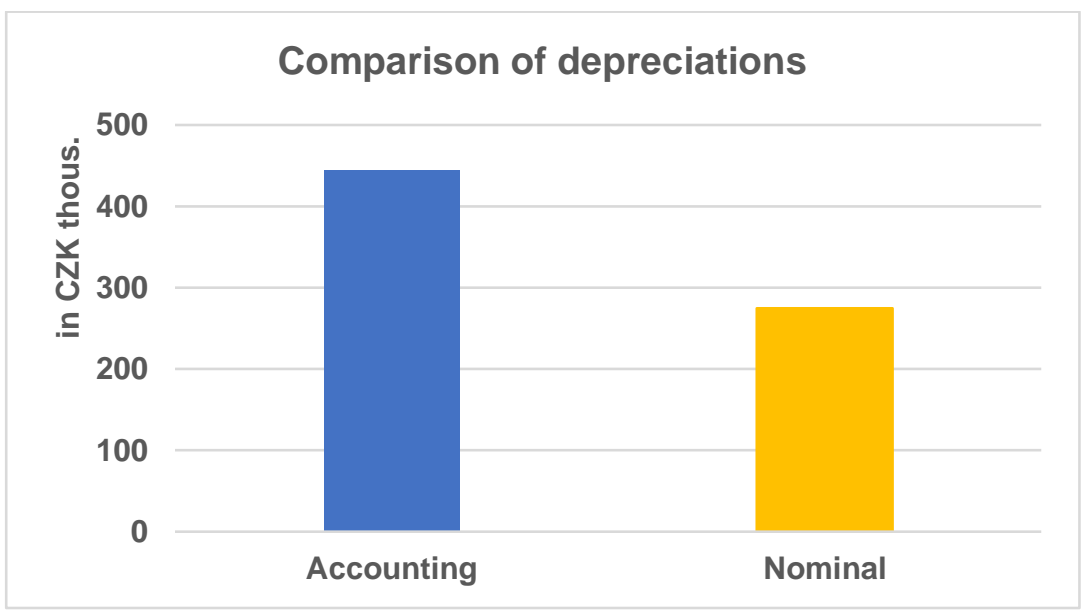

Figure 2 Difference of Cost and Accounting Depreciations of the Technologies of the Cleaning and Machining Shop Centre (in CZK thous.)

The analysis of the impact of accounting and cost depreciations on the calculations in the company was prepared with the Aggregate Calculation in the Sysklass information system, which is used for determination of product costs. For comparison of the impact of both types of depreciation, the final product calculation of an unspecified casting was used; where, in the first case, the calculation was made with the accounting depreciation and, in the second case, the cost depreciation was implemented. For the purposes of this paper, both calculations were made in a simplified manner. In both cases, the resulting values differ first in the line "Manufacturing overhead" where the above specified depreciation was inserted, but also in the resulting values of total cost of production (total CP) and in the value of the company's full cost of production (FCP). The above values are illustrated by Figure 3, where the difference in the total cost of production equals CZK 165 thous. Concerning the total value of FCP, the difference equals more than CZK 220 thous.

AGGREGATE CALCULATION (accounting depreciation)

Costs

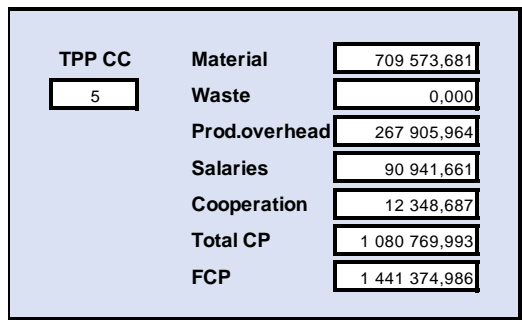

Intensity of work

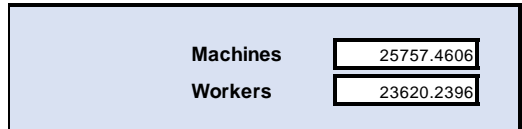

AGGREGATE CALCULATION (cost depreciation)

Costs

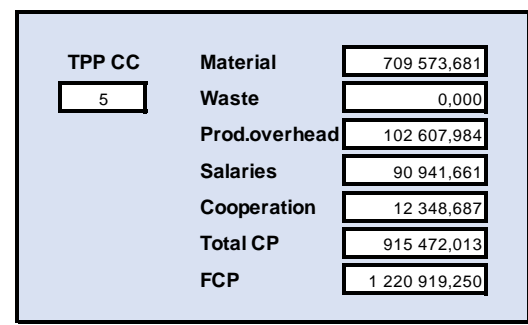

Intensity of work

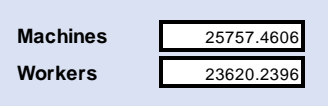

Figure 3 Comparison of the Costs for Manufacture of a Casting with the Use of Different Types of Depreciation

The above aggregate calculations, thus in fact the calculated cost of product, are used in the company as a basis for price calculations of final products. In such a case, we can justifiably say that depreciations are a source of funding, since the depreciation is collected from the customer in revenues. In contrast to other cost items, depreciation doesn't have to be accompanied by an adequately high monetary expense for acquisition of a resource, in the same period [8]. Therefore, funds created in such a manner should serve primarily for replacement of fixed assets at a time when it is necessary. 


\section{CONCLUSION}

In practice, there are many other examples which show the impact of depreciation applied in the right manner on the company's economic situation and cash flow, as well as its importance in management decision-making. Most of the examples cannot be covered in this paper. The above specified case study highlights a huge impact of appropriate definition of a depreciation plan on the calculation of product costs; and, thus, also on other factors of the company's economic growth. As it is also demonstrated by many professional searches, cost depreciation is one of the significant aspects of management accounting which is, however, often unnecessarily neglected in practice.

\section{ACKNOWLEDGEMENTS}

The work was supported by a specific university research of the Ministry of Education, Youth and Sports of the Czech Republic at VŠB-TU Ostrava No. SP 2021/71.

\section{REFERENCES}

[1] VALACH, J. Internal Resources and Some New Accesses to Investment's Financing. Czech Financial and Accounting Journal (Český finanční a účetní časopis). 2006, vol. 1, no. 1, pp. 62-73.

[2] OCELÁKOVÁ, P. Depreciation and Its Importance to Investment Decision in the Czech Republic. Czech Financial and Accounting Journal (Český finanční a účetní časopis). 2010, vol. 5, no. 3, pp. 75-92.

[3] Decree No. 500/2002 Coll. Decree No. 500/2002 Coll., implementing certain provisions of Act No. 563/1991 Coll., on accounting, as amended, for accounting entities that are entrepreneurs accounting in a double-entry bookkeeping system. [on-line] Available from: https://www.zakonyprolidi.cz/cs/2002-500\#cast4

[4] Act No. 586/1992 Coll., Income Taxes Act. [on-line] Available from: https://www.mesec.cz/zakony/zakon-odanich-z-prijmu/f1459884/

[5] ŠPERL, J. Depreciation of Tangible Assets (Odpisy hmotného majetku). Verlag Dashöfer [on-line] Available from: https://www.du.cz/33/odpisy-hmotneho-majetku-uniqueidmRRWSbk196FNf8jVUh4Erm6G5nY0UE3NbCYdJCZwds/

[6] VANČUROVÁ, P. Accounting, Tax and Controlling approach to Depreciation (Účetní, daňové a controllingové pojetí odpisü). DAUC.cz, 2019. [online]. Available from: https:/www.dauc.cz/dokument/?modul=li\&cislo=260480

[7] KRÁL, B. et al. Management Accounting (Manažerské účetnictví). Prague: MANAGEMENT PRESS, 2002. ISBN: 80-7261-062-7

[8] NEKVAPIL, T. Do Not Ask Accountants How to Manage Costs. 10 Stories about Calculations in Business. (Neptejte se účetních, jak řídit náklady. 10 přiběhů o kalkulacích v podnikání). Prague: Wolters Kluwer ČR, 2011. ISBN: 978-80-7357-596-0. 